\title{
Is Basel III a Panacea? Lessons from the Greek Sovereign Fiscal Crisis
}

Spyros Vassiliadis, Diogenis Baboukardos, Panagiotis Kotsovolos *

Abstract:

In the period 2007-2009 the global economy faced the most severe crisis after the Great Recession of 1929. In the aftermath of the crisis a substantially revised version of Basel II, named Basel III, was proposed, introducing new, tighter capital adequacy and liquidity guidelines. Basel III constitutes the new basic embankment against a possible crisis in the future. The same period these discussions were taking place for the new global regulatory framework, the most severe sovereign debt crisis the country ever faced burst out in Greece. One of the main victims of the crisis is the country's banking sector which is sustaining great pressure in its profitability, volume of deposits and credit growth, amongst others. Having as a starting point the Greek banking sector and the effects of the fiscal crisis on it, this paper discusses the new Basel III guidelines and their possible implications in times of turmoil. The new framework can play a crucial role in deterring a new financial crisis; however it should not be regarded as a panacea for all the shortcomings of banking sectors.

Keywords: Basel Accord III, Banking Regulation, Fiscal Crisis, Greece

JEL: E51, G28

DOI: $10.2478 / \mathrm{v} 10033-012-0007-5$

\section{Introduction}

The need for tighter and more robust supervision of the global financial system was apparent long before the 2007-2009 financial crisis. Even though Basel I was the first serious effort for the imposition of international regulation on the banking system, soon it was outrun and superseded by Basel II. The economic shock of the recent financial crisis led the Committee of Banking Supervision of Basel to propose a new global regulatory framework that aims for a stronger and more resilient banking system. Basel III constitutes the new basic buttress against a possible crisis in the future. The new framework not only strengthens global capital standards but also introduces global liquidity standards. It is argued that the implementation of Basel III will lead to a future of more capital, more liquidity and less risk.

Nevertheless, whether Basel III is a major reform or a hurried reflexive action to the recent financial crisis is still a question to be answered. Even though there is a broad consensus among the Basel Committee as well as in capital markets about the need for tighter rules, the effectiveness and possible failures of the new rules need to be identified. Such failures are manifested only in times of upheaval and crisis and hence the severe sovereign fiscal crisis in Greece is an interesting setting for showing

\footnotetext{
* Spyros Vassiliadis

Patras Hellenic Open University, Thessaloniki, Greece

E-mail: svas@acc.teithe.gr

\section{Diogenis Baboukardos}

Jönköping International Business School, Sweden, E-mail: diogenis.baboukardos@jibs.hj.se

\section{Panagiotis Kotsovolos}

Freelance Accountant

E-mail: pankotsovolos@yahoo.gr
} 
that the new proposed guidelines of Basel III should not be regarded as a panacea for all the shortcomings of the banking sectors worldwide, but as another arrow in the quiver for stabilizing the global banking system.

The remainder of the paper is organized as follows. The second section presents the main reasons that led to Basel III and outlines the basic advantages of the new framework. The third section provides an analysis of the current Greek banking sector and the consequences of the sovereign fiscal crisis on it. The fourth section critically analyzes possible implications of Basel III in times of crisis and finally the fifth section summarizes the paper.

\section{The Global Financial Crisis as a Trigger For More Rigorous Banking Supervision}

In the period 2007-2009 the global economy faced the most serious crisis after the Great Recession of 1929. The main cause of the financial crisis was the real estate bubble in the US and the consequent collapse of the high risk mortgage loans market (Edward, 2010). The stock markets began to shake while financial institutions exposed to toxic financial products faced default risks. The extensive separation of supervising authorities in the US did not allow the immediate diagnosis of the crisis which might have led to a prompt and effective confrontation of this. The crisis soon passed to the other side of the Atlantic: Northern Rock, a UK-based investment bank, was the first victim.

According to Arestis and Karakitsos (2011), there are two main causes of the "great recession" in the US: The significant redistribution of income from wage earners to the financial institutions and the great expansion of the liquidity in the world economy. During the period 19702007 the wage share in five of the G8 countries (France, Germany, Japan, UK and US) decreased by $10.5 \%$ on average. Moreover, the world liquidity between 1988 and 2008 increased from $8 \%$ to $19 \%$ of the world GDP. The income redistribution forced ordinary households to borrow and invest in financial and physical assets. That was made possible through financial liberalization and financial innovation (Arestis \& Karakitsos, 2011).

The global financial crisis brought on several discussions for the creation of a more resilient global banking system and led to a revised pact of Basel Accord II, named "Basel Accord III" that was presented and endorsed in 2010 by the G20 Leaders' Summit in Seoul. According to Caruana (2010), Basel III has four core advantages:
It increases the required level of capital: The higher the capital a bank holds, the less vulnerable it is in times of financial shocks. The new standards more than double the minimum quantity of common equity (Core Tier 1) a bank should hold, from $2 \%$ to $4.5 \%$, and it also increases the minimum Tier 1 capital from $4 \%$ to $6 \%$. Moreover, a minimum "capital conservation buffer" of $2.5 \%$ is required as an extra "equity cushion" (Kourtali, 2010). As a result, at the end of the transition period the minimum total capital required will be $8 \%$ plus $2.5 \%$ of the conservation buffer. These changes aim to construct a banking system much better prepared to withstand possible future periods of stress.

It improves banks' capital quality: A bank's common equity is comprised of various financial instruments. Each has different characteristics and hence a different lossabsorbing capacity (Zakka, 2010). The new guidelines not only increase substantially the required level of regulatory capital, but also provide a new, stricter definition of capital. According to the new definition several types of capital that proved to be risky and of uncertain quality are now excluded and hence the loss-absorbing capacity of banks is increased not only in terms of its quantity but also of its quality.

It reduces the systemic risk: The new framework is the first which takes into account the fact that financial institutions are not isolated entities that do not affect or are unaffected by their external environment. Basel III recognizes the interdependency of financial institutions and hence introduces tools for the effective management of systemic risk. As a supplement to the capital requirements discussed before, Basel III requires a minimum leverage ratio of $3 \%$ (which is subject to possible changes in the future) as well as a short-term liquidity coverage ratio and a longer-term net stable funding ratio. In addition, the new higher capital requirements and especially the introduction of a minimum "capital conservation buffer" will help banks to avoid procyclicality problems. Hence, as Caruana (2010) points out, "the new regulatory capital framework is that it provides what might be called a 'macroprudential overlay' to deal with systemic risk, that is, the risk of financial system disruptions that can destabilize the macroeconomy".

It gives sufficient time for a smooth transition: Inevitably a major reform such as Basel III needs sufficient time to be effective so as not to impede economic activity. Recognizing this fact, the Basel Committee has proposed a transition period of eight years. During this period the reforms will be effective gradually. For 


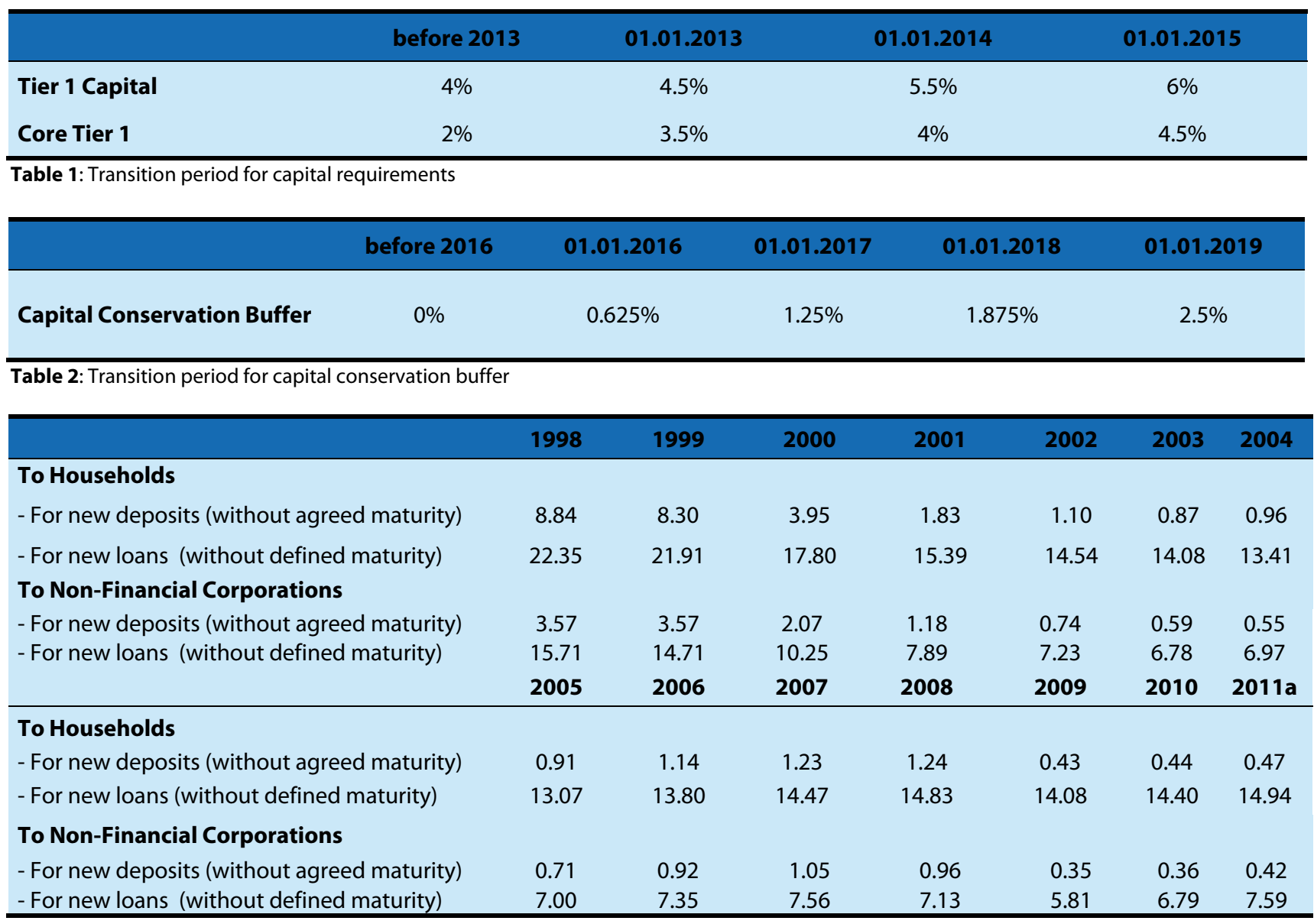

Source: Bank of Greece Database, http://www.bankofgreece.gr/Pages/en/Statistics/default.aspx

Table 3: End of year basic interest rates for loans and deposits

instance, the new definition of capital will be effective from January 2013 while the higher minima for Core Tier 1 and Tier 1 capital will be gradually adopted from January 2013 (Tables 1 and 2). The new standards shall be fully implemented in 2019.

\section{Greek Sovereign Fiscal Crisis: The Banking Sector in Turmoil}

The Greek banking sector can be characterized as one of the most active and dynamic sectors of the Greek economy. During the last two decades Greek banks have undergone tremendous changes which led to the substantial expansion of their activities both in Greece and abroad; especially in South Eastern Europe. The deregulation and harmonization of the European Union's banking/financial system, the privatization of most of the state-owned Greek banks and the introduction of Euro at the beginning of the $21^{\text {st }}$ century are just but a few factors which have created favorable conditions for the expansion of the Greek banks. A characteristic example is the evolution of interest rates (see Table 3 ). The introduction of a common currency in 2001 led to the rapid reduction in interest rates, which in turn led to a higher net interest rate for the banks and consequently more profits, a lower cost of borrowing, new investments and higher consumption, amongst others. Figure 1 describes one of these favorable consequences. From 2001 until 2009 the aggregate actual consumption of individuals increased by almost $70 \%$.

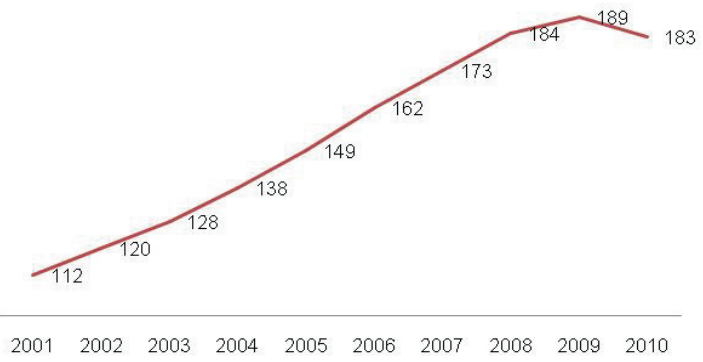

Source: Hellenic Statistical Authority Database Figure 1: Actual annual individual consumption (in bil. €) 


\begin{tabular}{lcccc}
\hline & $\mathbf{2 0 0 8}$ & $\mathbf{2 0 0 9}$ & $\mathbf{2 0 1 0}$ & $\mathbf{2 0 1 1 a}$ \\
\hline Tier $\mathbf{1}$ & & & & $11.1 \%$ \\
Alpha Bank & $8 \%$ & $11.6 \%$ & $11.9 \%$ & $11.6 \%$ \\
EFG Eurobank & $8 \%$ & $11.2 \%$ & $10.6 \%$ & $11.2 \%$ \\
National Bank & $10 \%$ & $11.3 \%$ & $13.1 \%$ & $8.6 \%$ \\
Piraeus Bank & $8 \%$ & $9.1 \%$ & $8.4 \%$ & \\
\hline
\end{tabular}

Source: Banks' Annual Financial Statements 2009, 2010 and Interim Financial Statements 2011

Table 4: Tier-1 capital adequacy ratio of the "Big-4" Greek banks under Basel II rules

\begin{tabular}{lrrrrrrr}
\hline & 2005 & 2006 & 2007 & 2008 & 2009 & 2010 & $2011 a$ \\
\hline Alpha Bank & 634.14 & 800.76 & 985.26 & 625.63 & 501.82 & 216.37 & -511.03 \\
EFG Eurobank & 676.00 & 832.00 & 1050.00 & 818.00 & 398.00 & 136.00 & -956.00 \\
National Bank & 943.09 & 1268.30 & 1902.93 & 1937.01 & 1252.07 & 637.63 & -1.280 .83 \\
Piraeus Bank & 304.62 & 556.55 & 785.31 & 385.79 & 286.62 & 10.75 & -1.003 .8 \\
Sector* & 3312.67 & 4367.74 & 6498.24 & 4243.74 & 1902.05 & -282.85 \\
\hline
\end{tabular}

Notes: *Aggregate Results of the 14 Listed Banks on the ASE: ALPHA BANK, ATE BANK, ATTICA BANK, EFG EUROBANK, MARFIN POPULAR BANK, MARFIN EGNATIA, PROTON BANK, T BANK, GENERAL BANK, NATIONAL BANK, COMMERCIAL BANK. POST BANK, BANK OF CYPROUS, PIRAEUS BANK

Source: Corporate Benchmarking Financial Analysis Database, Hellastat Inc.

Table 5: Profit (Loss) before taxes of the "Big 4" Greek banks and of the banking sector (in mil. $€$ )

\begin{tabular}{lrrrrrr}
\hline & $\mathbf{2 0 0 6}$ & $\mathbf{2 0 0 7}$ & $\mathbf{2 0 0 8}$ & $\mathbf{2 0 0 9}$ & $\mathbf{2 0 1 0}$ & $\mathbf{2 0 1 1 a}$ \\
\hline Households & 141070 & 158414 & 185424 & 196860 & 173510 & 156116 \\
Non-financial corporations & 30612 & 35107 & 38185 & 35877 & 29810 & 25767 \\
General Government & 5979 & 7011 & 8258 & 7940 & 13269 & 9102 \\
Insurance corporations & 1357 & 1859 & 1810 & 1787 & 2377 & 2341 \\
Other financial institutions & 1898 & 2549 & 2201 & 3007 & 3908 & 3955 \\
Total & $\mathbf{1 8 0 9 1 6}$ & $\mathbf{2 0 4 9 4 0}$ & $\mathbf{2 3 5 \mathbf { 8 7 8 }}$ & $\mathbf{2 4 5 \mathbf { 4 7 0 }}$ & $\mathbf{2 2 2 ~ 8 7 4}$ & $\mathbf{1 9 7 2 8 1}$ \\
\hline
\end{tabular}

Source: Bank of Greece Database, http://www.bankofgreece.gr/Pages/en/Statistics/default.aspx

Table 6: Deposits and repos of domestic residents (in mil. $€$ )

Today, however, the prosperous years of the 00 's are only a fond memory. While these lines are being written, a super deal has probably been completed between the second and the third biggest Greek banks. The Boards of Directors of Alpha Bank and EFG Eurobank have come upon an initial agreement for the two banks being merged, forming a banking colossus in South East Europe and one of the top 25 largest banking groups in the Eurozone. The reasons that lead to this merger are far different from those that led to a series of mergers and acquisitions during the $90 \mathrm{~s}$. The merger is not a strategic movement for further expansion but simply a matter of survival: In the first half of 2011 the aggregate losses after taxes of the two banks reached $€ 1$.3bil. While the aggregate impairment losses on the Greek Government's bonds net of taxes were more than $€ 1$.2bil. In addition, a few weeks before banks reported their interim financial statements, European Banking Authority stress tests ${ }^{1}$ revealed inadequacies in EFG Eurobank's capital', speeding up the realization of rumors for the oncoming mergers among Greek banks.

At the same time, however, as Table 4 shows, Greek banks sufficiently cover the capital adequacy

\footnotetext{
${ }^{1}$ For a detailed discussion http://stress-test.eba.europa.eu/

${ }^{2}$ Vaughan et al. (2011) characterize EFG Eurobank as one of Europe's eight "problem children" due to the fact that it was found "...to have insufficient reserves to maintain a core Tier 1 capital ratio of 5 percent in the event of an economic slowdown."
} 


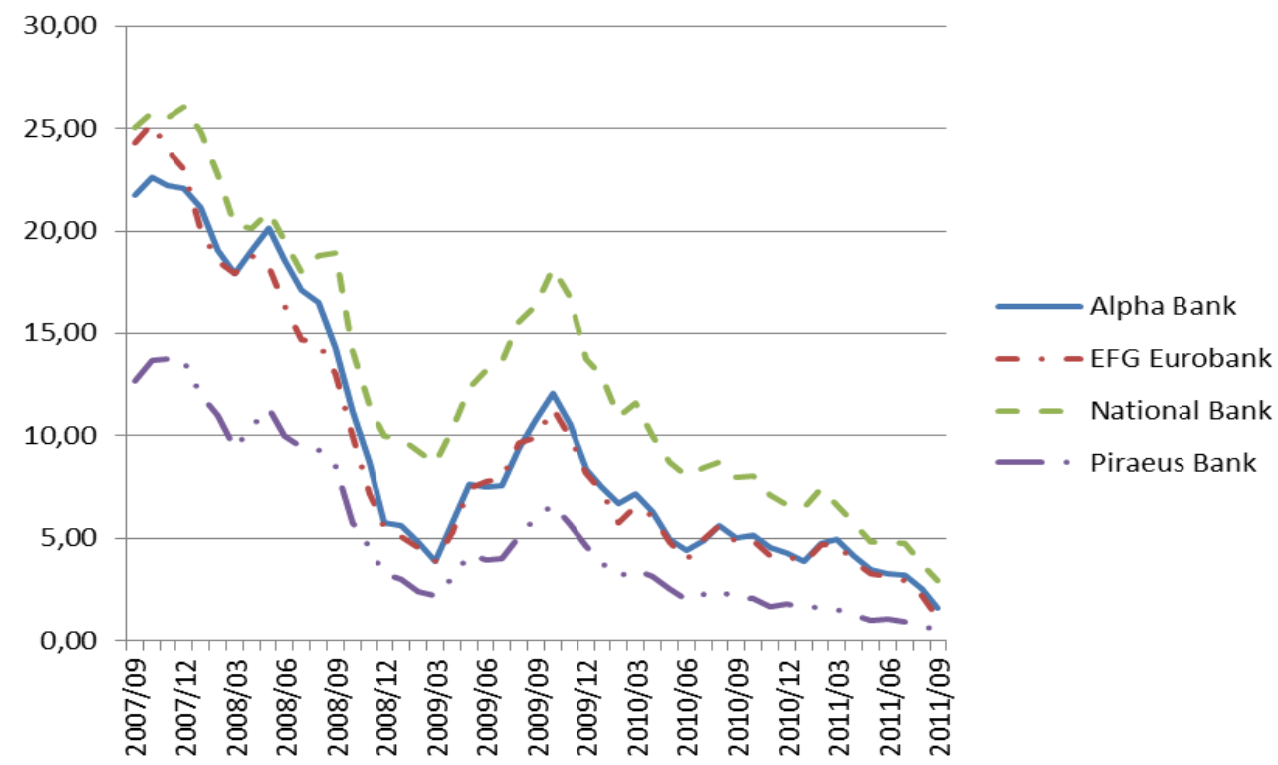

Source: Athens Stock Exchange

Figure 2: Average daily stock prices of the "Big 4" Greek banks by month for the period September 2007 - September 011 (in €)

requirements not only of Basel II but also of the newly proposed Basel III. Moreover, the recent stress tests of the European Banking Authority showed that three out of four major Greek banks (apart from EFG Eurobank) have a strong enough capital position to absorb the economic shocks resulting from the designed adverse scenarios. Hence, taking into consideration the ongoing merger of EFG Eurobank with Alpha Bank, it could be claimed that the backbone of the Greek economy is resilient. However, such an argument would be at best superficial. Even though Greek banks have succeeded in reporting an adequate level of capital, a more precise look into their fundamentals reveal some facts that are at the very least unsettling. In the space below the most important of those facts (namely profitability and performance, volume of deposits, credit growth and quality) are discussed.

Table 5 gives an illustrative picture of the deterioration of Greek banks' performance over the last few years. In 2008 the aggregate profits before taxes for all listed Greek banks (except for the Central Bank of Greece) dropped by 35\% in comparison to 2007. In 2009 profits ware less than half of 2008, while in 2010 the banking sector on the Athens Stock Exchange (ASE) presented aggregate losses of almost $€ 283$ mil. Moreover, the interim financial statements for the first six months of 2011 which were published in late August 2011 revealed that the results of the four biggest Greek banks would have been extremely negative even in case they had not had to recognize impairment losses on the Greek
Government's bonds. Specifically, profit before taxes and before impairment losses on the Greek Government's bonds net of tax would have been almost $90 \%$ less than in the same period of 2010 for Alpha Bank and the National Bank of Greece, while the Eurobank would have had to recognize losses of nearly $€ 126$ mil. It should also be mentioned that Piraeus Bank would have been the only one of the "Big 4" with relatively positive results, mainly due to the fact that it was the only one of the four banks which recognized impairment losses in the interim financial statements of 2010.

However, profitability is not the only problem the Greek banks are facing. Another alarming issue is the steep decrease of domestic residents' deposits and repos. In an 18-month period (end 2009 - June 2011), Greek banks have lost almost $20 \%$ of their domestic deposits (Table 6). This loss is translated into absolute numbers as $€ 22.5 \mathrm{bil}$. and $€ 25.5 \mathrm{bil}$. in 2010 and the first six months of 2011, respectively. In this year and a half the companies' accounts presented the most rapid drop as a percentage (almost 30\%), while households' deposits presented the most rapid drop in absolute numbers (more than $€ 40$ bil.).

The causes of this vicious circle of illiquidity in which the Greek economy is entrapped are multiple. First, the uncertainty of the economic environment: the unending rumors of a possible default by Greece prohibit any capital inflow from foreign investments and also lead depositors to transfer their deposits to "safer" economies abroad. In addition, the consecutive austerity measures of the Greek government, and especially the increase of 


\begin{tabular}{|c|c|c|c|c|c|c|}
\hline & 2001 & 2002 & 2003 & 2004 & 2005 & 2006 \\
\hline Private Sector & 74601 & 87177 & 103848 & 123754 & 149639 & 179158 \\
\hline - Corporations & 50908 & 55843 & 63619 & 71432 & 81008 & 93574 \\
\hline - Individuals & 23693 & 31334 & 40229 & 52323 & 68630 & 85584 \\
\hline Housing & 15516 & 21060 & 26589 & 33843 & 45187 & 56909 \\
\hline Consumer & 7852 & 9755 & 12385 & 17025 & 21794 & 26540 \\
\hline Other loans & 325 & 518 & 1255 & 1455 & 1649 & 2135 \\
\hline & 2007 & 2008 & 2009 & 2010 & $2011 a$ & \\
\hline Private Sector & 215088 & 249324 & 249321 & 257474 & 253102 & \\
\hline - Corporations & 111288 & 132457 & 130042 & 139726 & 137398 & \\
\hline - Individuals & 103801 & 116866 & 119280 & 117747 & 115704 & \\
\hline Housing & 69075 & 77386 & 80225 & 80155 & 79442 & \\
\hline Consumer & 31915 & 36412 & 36023 & 35061 & 33572 & \\
\hline Other loans & 2811 & 3068 & 3032 & 2532 & 2690 & \\
\hline
\end{tabular}

Source: Bank of Greece Database, http://www.bankofgreece.gr/Pages/en/Statistics/default.aspx

Table 7: Credit to domestic private sector by domestic financial institutions (in mil. $€$ )

\begin{tabular}{|c|c|c|c|c|c|}
\hline & 2006 & 2007 & 2008 & 2009 & 2010 \\
\hline Housing loans & $3.4 \%$ & $3.6 \%$ & $5.3 \%$ & $7.4 \%$ & $10 \%$ \\
\hline Consumer loans & $6.9 \%$ & $6 \%$ & $8.2 \%$ & $13.4 \%$ & $20.5 \%$ \\
\hline Business loans & $6 \%$ & $4.6 \%$ & $4.3 \%$ & $6.7 \%$ & $8.7 \%$ \\
\hline Total & $5.4 \%$ & $4.5 \%$ & $5 \%$ & $7.7 \%$ & $10.4 \%$ \\
\hline Accumulated provisions over NPLs & $61.8 \%$ & $53.4 \%$ & $41.5 \%$ & $41.5 \%$ & $44.7 \%$ \\
\hline
\end{tabular}

Source: Bank of Greece Annual Reports 2006 - 2010

Table 8: Non-performing loans (NPLs)

both indirect and direct taxes as well as salaries' and pensions' cut off have reduced consumption dramatically, as well as economic activity, with the undesirable but also inevitable consequences of an increase in unemployment and further decreases in deposits, since households have seen their real purchasing power diminish, and have tried to compensate by using their deposits. Hence, banks are watching their cash reserves substantially decreases, having as a last resort for liquidity the European Central Bank.

Another negative aspect of the current condition of the Greek banking system is the cessation of lending activity. The total amount of credit to the domestic private sector has remained almost stable for the last three and a half years following a 7-year period of rapid expansion in which the annual credit growth rate fluctuated between $16 \%$ and $21 \%$ (Table 7 ).
Beyond the above findings, extreme increase of nonperforming loans in the last few years should also be highlighted. Table 8 shows that from 2008 to 2010 housing and business non-performing loans doubled, while respective consumer loans increased by $150 \%$. The halt in credit growth, as well as the increase of nonperforming loans, are two more factors aggravating the illiquidity problem of the Greek banking system. Moreover these two factors deteriorate the profitability of banks due to the fact that the lack of credit growth means stagnation of turnover, and the increase of nonperforming loans means increases in costs due to the loans' write-offs.

Last but not least, it should be underlined that neither Basel II nor Basel III's capital adequacy requirements seem to provide strong enough assurance for appeasing markets' concerns over Greek banks' ability to cope with a possible hair cut on Greek Government bonds. This is 
clearly evidenced by the banks' market capitalization. Figure 2 shows the extremely negative pricing of the "Big 4" Greek banks' shares after October 2009. Specifically, from the end of 2009 until September 2011, Alpha Bank's, EFG Eurobank's, National Bank's and Piraeus Bank's stock prices have lost $84 \%, 88 \%, 79 \%$ and $89 \%$ of their market value, respectively.

\section{Possible Implications of Basel III: What the Case of the Greek Crisis Shows}

Even though the new framework can play a crucial role in deterring a new financial crisis, it should not be regarded as a panacea for all the shortcomings of the banking sectors. In the space below the basic drawbacks of the new guidelines are discussed.

The Basel Accord III will become fully effective in 2019, but it is reasonable to expect many financial institutions will start following the new guidelines much earlier. The early adoption of the new capital and liquidity requirements would be a signal to the markets that the bank in question is "healthy enough", enhancing markets' confidence. Nevertheless, as it becomes clear from the analysis of the Greek banking sector, simple compliance with the minimum numerical thresholds does not guarantee the sustainability of a bank and the safety of the system. Wolf (2010) claims that the new capital requirements are still very low and a possible crisis in the future may lead to new bank failures. As he points out "...equity requirements need to be very much higher, perhaps as high as 20 or 30 per cent...It is only because we have become used to these extraordinarily fragile structures that this demand seems so outrageous". The Greek example provides clear evidence that confirms Wolf's point of view: In order to survive, Greek banks need either to proceed to mergers creating disproportionally big (to the size of the Greek banking market) institutions or to ask for governmental help. Hence the available capital, even though adequate according to Basel III, would still not be enough.

More than that, under Basel III banks will have less capital available for their activities, which will lead to more expensive capital for borrowers. In times of fiscal crisis, private investments play a key role for helping an economy to get back on its feet. For example, nowadays Greece is looking for new private investments in order to enhance its poor records, reduce its unemployment rate and increase public revenue. A higher cost of capital might be a discouraging factor for new investments and consequently might hinder the recovery of the economy.

The basic weakness, however, of Basel III, that the Greek crisis reveals, is the idea that banks should hold more capital for riskier assets than for safer ones. For instance, investing in Western European sovereigns' bonds is safer than giving mortgages to unemployed individuals. Nevertheless, the ongoing debt crisis in Greece and many other member states of the Eurozone reveals that there is actually no risk free asset and hence the risk weighting approach of Basel III is questionable. In addition to that, the risk weighting concept might be proven even more problematic if credit rating agencies are included in the equation. The recent financial crisis revealed that these agencies were unable to recognize the hidden risks behind complicated financial products backed by unreliable mortgages. They gave these products high ratings and equated them with US or German bonds. Under Basel III weighting risk guidelines those products would have been regarded as low risk and hence almost no capital would have been reserved for them. Hence, it can be claimed that Basel III makes no realistic assumptions (i.e. sovereigns do not default and rating agencies do not make mistakes).

Last but not least, it should be pointed out that Basel III came into existence as a response to problems that were revealed by the global financial crisis. The implementation of the new guidelines by itself is not enough to eliminate the problems and the stresses of the global financial system. Additional measures such as better monitoring of the banking system, improved national and international enforcement mechanisms for the new Basel III, clear separation of commercial from investment banks and disincentives for the formation of "too big to fail" financial institutions should have desirable results enhancing the role of Basel III.

\section{Summary}

The implementation of Basel III will considerably increase the quality of banks' capital and will raise its required levels. In addition it will provide a "macroprudential overlay" to better deal with systemic risk. Today the Greek banking sector is under tremendous pressure due to the severe sovereign fiscal crisis. Major Greek banks face a number of serious problems such as low/negative profitability, steep reduction of deposit volume, negative credit growth and an increasing number of non-performing loans. The fact that these 
banks fulfill the newly proposed Basel III capital adequacy requirements shows that simply complying with minimum numerical thresholds does not guarantee the sustainability of a bank and the safety of the system. The Greek crisis reveals possible negative implications of the new Basel III: Capital requirements might still be too low, the cost of capital might be increased due to less available capital and the risk weighting approach might prove inadequate. Better banking regulation is critical but not enough. The promotion of financial stability requires a broad policy framework in which Basel III should be just one aspect. A number of suggested reforms could include: better monitoring of the banking system, improved national and international enforcement mechanisms for the new Basel III, clear separation of commercial from investment banks and disincentives for the creation of "too big to fail" financial institutions.

Certainly, the analysis of only one banking system, in our case the Greek banking system, is not enough to prove or deny sustainability and viability of Basel Accord III. Further research on other banking systems can considerably help the discussion of whether or not Basel III is a truly revolutionary reform or just a short run solution to the emergence of a severe crisis. $[$.

\section{References}

Arestis P. and Karakitsos E., (2011) "An Anatomy of the Great Recession and Regulatory Response", proceedings of the $11^{\text {th }}$ international conference of the Economic Society of Thessaloniki on "Global Crisis and Economic Policy", Thessaloniki, November 2010.

Bank of Greece "Credit Aggregates" available:

http://www.bankofgreece.gr/

Pages/en/Statistics/monetary/financing.aspx [Accessed 2 September 2011]

Bank of Greece "Deposits", available:

http://www.bankofgreece.gr/Pages

/en/Statistics/monetary/deposits.aspx [Accessed 2 September 2011]

Bank of Greece 2006, 2007, 2008, 2009 and 2010 Annual Reports, available:

http://www.bankofgreece.gr/Pages/el/Publications/GovReport.aspx?Filt er_By=8 [Accessed 2 September 2011]

Bank of Greece "Bank Deposit and Loan Interest Rates", available: http://www.bankofgreece.gr/Pages/en/Statistics/rates_market s/deposits.aspx [Accessed 2 September 2011]

Caruana J., (2010), "Basel III: towards a safer financial system", 3rd Santander International Banking Conference, Madrid, http://www.bis.org/speeches/sp100921.pdf

Corporate Benchmarking Financial Analysis Database, Hellastat Inc., available: http://www.cbfa.gr/criteria.do [Accessed 2 September 2011]

Edward J. P., (2010), "Causes and consequences of the US real estate crisis", http://www.marketobservation.com/blogs/index.php/2010/10/28/edwa rd-j-pinto-former-chief-credit-officer-of-fannie-mae-1987-1989-aboutcauses-and-consequences-of-the-us-real-estate-crisis?blog=9

European Banking Authority "EU - Wide Stress Testing Exercise", available: http://stress-test.eba.europa.eu/ [accessed 1 September 2011]

European Banks: Chest Pains, The Economist, August-Sept. $2^{\text {nd }} 2011$.

Financial Contagion: Fear of Fear itself, The Economist June $25^{\text {th }}$-July $1^{\text {st }} 2011$.

Hellenic Statistical Authority "Final Consumption Expenditure of Households" available: http://www.statistics.gr/portal/page/portal/ESYE/PAGE-

themes?p_param $=$ A0702\&__ $\quad$ param $=S E L 39 \& y \_p a r a m=T S \& m y t a b s=0$ [Accessed 2 September 2011]

International regulatory framework for banks (Basel III), http://www.bis.org/bcbs/basel3.htm

Jablecki J., (2009) "The Impact of Basel I Capital Requirements on Bank Behavior and the Efficacy of Monetary Policy", International Journal of Economic Sciences and Applied Research, vol.2, Issue 1.

Karatzas T., (2003) "The Greek Banking System", $96^{\text {th }}$ Board Meeting of the Banking Federation of the European Union, Athens, available: http://62.1.43.74/70milies-

parousiaseis/UplFiles/omilies/board/Karatzas4-4-2003.pdf

Kourtali E., (2010), "Banks: Positives and negatives of Basel III", http://www.kerdos.gr/default.aspx?id=1331952\&nt=103

Kourtali E., (2010), "Basel: Stricter rules with long period of grace for the banks", http://www.taxheaven.gr/news/news/view/id/6314, Source Kerdos

Petsas S., (2009), "World economic crisis: Causes and its confronting", http://blogs.eliamep.gr/petsas/pagkosmia-ikonomiki-krisii-eties-ke-i-antimetopisi-tis-2/

The 2010 Annual Report of the Governor of Bank of Greece, April 2011

The Basel Committee's response to the financial crisis: report to the G20, http://www.bis.org/publ/bcbs179.pdf [Accessed October 2010]

Vaughan L., Finch G. and Moshinsky B., (2011) "Stress Tests Pressure Europe's 'Problem Children' Banks to Bolster Capital", available:http://www.bloomberg.com/news/2011-07-15/eighteuropean-banks-fail-stress-tests-with-3-5-billion-capital-shortfall.html

Wolf M. (2010) "Basel: the mouse that did not roar", Financial Times website, available at http://www.ft.com/intl/cms/s/0/966b5e88-c03411df-b77d-00144feab49a.html\#axzz 1 tHhAgngl

Zakka V., (2010), "Bank of Greece: Basel III puts new terms in the banking market", available athttp://www.bankersreview.gr/default.asp?pid=9\&la $=1 \& \mathrm{clD}=5 \&$ arld $=6$ 58 